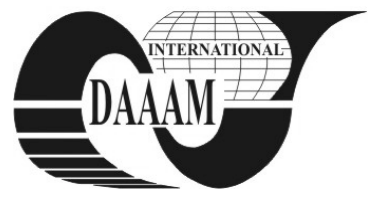

Annals of DAAAM for 2011 \& Proceedings of the 22nd International DAAAM Symposium, Volume 22, No. 1, ISSN 1726-9679 ISBN 978-3-901509-83-4, Editor B. Katalinic, Published by DAAAM International, Vienna, Austria, EU, 2011 Make Harmony between Technology and Nature, and Your Mind will Fly Free as a Bird Annals \& Proceedings of DAAAM International 2011

\title{
FAMILY VIOLENCE AND ITS CONSEQUENCES IN THE EDUCATIONAL PROCESS
}

\author{
KURTUHUZ, A[ndreea] M[aria]; RADU, D[aniela] L[iana]; BACIU, G[eorge]; ANGHEL, C[ornel]; \\ SANTI, A[ncuta] E[lena] \& POPESCU, A[lexandra] P[olixenia]
}

\begin{abstract}
The human history, said H.G. Wells, becomes more and more a race between education and catastrophe. And that is happening only because the human violence has risen up to unpredictable limits while the education is still looking its way. Young men, including pupils, are dealing with different kinds of violence, from the child abuse in his own family to street aggression, from the violence caused by social or political ebulliences to open conflict or declared war. No matter the shape it has, the violence impact is highly harmful and it has huge effects on young people; it destroys the self confidence and decreases the feeling that they can have their own positive contribution in the society.
\end{abstract}

Key words: education, family violence, juvenile delinquency.

\section{INTRODUCTION}

One of the highest forms of the violence has its roots in the family background, there where the children should have intergroup relationships, the basis for his socialisation and the development of his own personality, his own and different complexion.

\section{DELIQUENCY ON FASHION}

It all begins with parents neglect towards their children, the worry too hard for the day of tomorrow, it makes them leave under control the faith of their children and it grows also the lack of attention for the children needs and the way they act in different occasions, affecting their perceptions and their innocent thoughts. And to all these we can add also the band or the gang influences, the disrespect and the lack of sympathy for the people around them. The young men live their lives as if they own the world, they believe that and they act as if they were born managing it. A huge influence on these "little delinquents" is pushed by the crazy madness for money, by the fact that they are raised into a bad and sad alcoholic environment where they learn to reach whatever they wish in different and disordered manners, without keeping count of any kind of law, restriction and sometimes of common sense.

Children often test the limits and boundaries set by their parents and other authority figures. Among adolescents, some rebelliousness and experimentation is common. However, a few children consistently participate in problematic behaviors that negatively affect their family, academic, social, and personal functioning. These children present great concern to parents and the community at large. The prevention of delinquency requires identifying at-risk individuals and their environments before delinquent activity and behavior occur, and then removing such risk factors or strengthening resistance to the risk factors already present. The most logical starting place for prevention efforts is the family (Durkheim, 2005).

Their determination for rising from the ranks, for fun or for leadership of the gang makes the young people lose their control. They want to copy other people because they reach to a point where they don't know themselves anymore. They put in practise all they see on TV, internet, around them and unfortunately in their families: violence, neglect, disinterest, revenge. Many teenagers abandon school and the chance of becoming a delinquent is higher and higher with any generation.

Minors may be considered youthful offenders if they engage in acts that are illegal for people of any age. This includes minor crimes, such as shoplifting, disorderly conduct, and petty theft. It also includes crimes that are serious, such as those involving a deadly weapon, stealing large sums of money, rape, and murder. There are also some acts that are only considered crimes when youthful offenders commit them. For example, a minor may be guilty of a crime in some places if he buys and consumes alcoholic beverage, runs away from home, or skips school without his parents' permission

Juvenile delinquency is more often today, is the mask on fashion of those young men which are beginning to grow up and so they pass through a time of life with multiple changes which involve behaviour disorders and personality crisis.

\section{MORE THAN PHYSICAL ABUSE}

Every October, we pause at least once during Domestic Violence Awareness Month to acknowledge how grateful we are to have chosen the partner that we did. When we read the statistics and watch the news reports about how many people are being beaten, controlled or otherwise abused by their spouses, boyfriends or girlfriends, we consider ourselves lucky to be in a relationship that is based upon trust, love and respect.

If you are the parent of a teenager who is dating or in an exclusive relationship, you may want to hold off on assuming that your family hasn't been affected by relationship violence. Experts estimate that one-third of teens have experienced some type of abuse within a relationship, and that about one in 10 has been physically abused by a romantic partner.

Regardless of how good a parent you are, or how close your family is, this doesn't mean that your teen is immune from the effects of relationship violence. Relationship-based abuse happens to good kids, smart kids and strong kids and though you'd rather not even think about it, the harsh reality of the matter is that it can happen to your kid, too.

As the estimates in the previous section indicate, physical violence is far from the only type of abuse that occurs within teen (or, for that matter, adult) relationships. Common types of teen relationship violence include verbal harassment, emotional abuse and controlling or possessive behaviors.

A March 20, 2008, article on the WebMD website describes a number of the ways in which a teen can be manipulated or exploited by an abusive partner, and notes that no teens are automatically exempt from these types of unhealthy experiences. Abusers try to manipulate their dating partners by making all the decisions, putting them down in front of friends, threatening to kill themselves, stalking them or forcing them to have sex (Perry, B. 2001).

Like adult domestic violence, teen relationship abuse affects all types of teens, regardless of how much money their 
parents make, what their grades are, how they look or dress, their religion or their race. Teen relationship abuse occurs in heterosexual, gay and lesbian relationships.

On its website, the National Teen Dating Abuse Helpline lists four simple statements to help teens remember that physical abuse isn't the only symptom of an unhealthy relationship:

- Love is Trusting - it isn't keeping tabs with obsessive calls and texting

- Love is Secure - it isn't being jealous, suspicious or paranoid.

- Love is Accepting - it isn't telling someone what to do, what to wear or how to act.

- Love is Freedom - it isn't about possessing someone or anything

\section{THE SOCIETY- A BIGGER FAMILY}

The society is a place where human "trashes" are pleased to develop their relationships, their gangs and to pervert the humanity inside all of us, as Rousseau said. The poorness is one of the bleeding wounds of the society and hurts more and more families. This is the point where those innocent, pure and clean teens are pushed to deals with not proper social values: drugs, prostitution, holdup, murder. The society' periphery is coming over us, burking us, destroying us...

It's all about a vicious circle: the violence created in the family leads to the violence from the society and backwards, a society that accepts violence in any life' sphere, put an accent on the violence trends from the family. We can say that the roots of the violent behaviour are increasing more with the bad influences from the environment, especially from the acts of "other important people" for him.

Today, more than never, the psychologists and the Church point out to the real danger that television and internet are for the child and ten psyche, suggesting the existence of clear bounds between seeing very aggressive TV shows or cartoons and the violent behaviour of the child, copying what he saw and accepting that as something natural from his own behaviour (Neamţu, G. \& Stan, D. 2005).

Another study reveals that violence confirms the fact that lower education or the lack of it in some cases, it is associated in a higher proportion with aggressive behaviours, depending one on each other.

\section{SOCIETY-EDUCATION VALUES}

A proper educational system agreed by the society values, but also by community moral represents the most effective way to eliminate the society negative effects. Concerning the educational system, beyond the manual point or the social perception, there is the teacher-taught relationship in which it should be compulsory the instructive-education report based on the balance between authority and freedom. Only in this way education can become a social control.

Education being an intergenerational collaboration-the adult, the parent or the teacher- as representatives for social maturity, they have some special prerogatives: authority, control, coercion, sanction. The young man must admit and obey to these hardship rules resulted from those social characteristics of this report.

The adult-teen relationship is a socialize relation where some models and social values are taught in the same way that school do that. But when the adult from home doesn't collaborate educationally with the minor, left in the hands of violence, the school effort is for nothing because it had to deal with violent acts of the young man who believes him as being too free, the master of his own. The teacher authority would be efficient in the elimination of deviant behaviour if it had been a moral authority, an ethical approach and straight.

In this way, the teacher has two conditions and qualities: the first is the will and the second is the authority. But authority involves trust and the teens cannot have trust in someone who hesitates, someone who comes back and turn on its decisions. This condition is important only if the teacher truly feels inside of him this authority and he is trying to make it felt also by the child. The teacher, as a representative of the authority, always feels the temptation of a power abuse, of teacher-taught relationship violence as the principle said: „I am mature, so I think well". This state of mind, named as school megalomania by E. Durkheim, is resulted from the exaggeration of teacher's feeling about his own power towards the taught pupil. In fact, it is a result of the psychosocial gap between the two of them. In this case, the educational relationship is inefficient, even noxious for the child which is traumatized and becomes violent, not because he took as himself the teacher's model, but because he needs to suppress, to dominate others by force.

The true authority includes neither vanity nor pedantry. It consists in the respect that the teacher has toward his "position". The authority without freedom cannot create a man with a healthy personality, able to respond to social, political, economical and cultural requests of the society.

But freedom should be the daughter of a well understood authority. , Being free - said Durkheim - doesn't mean to do what you like, but being master of yourself, meaning to act rationally and do one's duty. To teach a child the forbearance it must be used the teacher authority, but his authority is nothing but an aspect of the duty and sense authority" (Durkheim, E. 2005).

The child should recognize it in the teacher' word and give up to a piece of his freedom, knowing that too much freedom leads to the lack of a compared model, to chaos and dehumanisation. Only in this way he will know later to find it in his own conscious and obey it.

A possible imbalance between authority and freedom will lead to despotism or to the missing of the social moral. In both cases, only the violence wins. Its victory means the extinction of beauty, of love, of naturally behaviour.

\section{CONCLUSION}

The school should open to the society and become an internal life based on authority-freedom balance in education. Considering school as a "scholar society"where collective moralisation exists, Durkheim says that the teacher should precise the group social sense, because inside the group are learnt the bases for social formative activities, the rules are assimilated, authority and love are well understood.

The main problem of today school is discipline, the lack of familial education, the lack of minimum morality. It can be sadly seen that teens are a part of us, of the sweet tear left no where. We can crush between fingers, or kiss as if we had mistaken with ourselves.

\section{REFERENCES}

Durkheim, E. (2005). Education and sociologie, [9e éd.] Presses Universitaires de France, ISBN 2-13-055329-X, Paris

Neacşu, I.; Mareş, R. \& Nica, M. (2003). The youth and the education for nonviolence values, Ed. Semne, ISBN: 973624-149-1, Bucureşti

Neamţu, G. \& Stan, D. (2005). Caseworker. Studies and applications, Ed. Polirom, ISBN 973-681-263-4, Iaşi

Perry, B. (2001). The neurodevelopmental impact of violence in childhood. In D. Schetky \& E. Benedek (Eds.), Textbook of child and adolescent forensic psychiatry, Washington, DC: American Psychiatric Press, (pp. 221-238).

Stoica, S. (2010). Durkheim' ethique, $2^{\text {nd }}$ ed., Ed. Ştiinţifică, Bucureşti 